Studia Philosophiae Christianae

UKSW

$51(2015) 4$

ANDRZEJ WALESZCZYŃSKI

\title{
O DOŚWIADCZENIU POWINNOŚCI I JEZZYKU WARTOŚCI MORALNYCH ROMANA INGARDENA
}

\begin{abstract}
Streszczenie. Roman Ingarden, opisując rzeczywistość moralną, posługiwał się językiem wartości. Niniejszy artykuł przedstawia opis wartości moralnych i analizę terminologii stosowanej do ich charakterystyki i wyjaśniania sposobu ich istnienia. Istotne znaczenie dla teorii wartości moralnych ma doświadczenie powinności i problematyka normatywności. Zbadanie obu zagadnień prowadzi do pytań o sposób powstawania nowych klas wartości moralnych i rozpoznawania powinności do ich realizacji. Przeprowadzone badania pokazują także trudności związane ze stosowaniem języka wartości w komunikacji zagadnień moralnych.
\end{abstract}

Słowa kluczowe: doświadczenie powinności, normy, język wartości, wartości, Roman Ingarden

1. Specyfika wartości moralnych. 2. Doświadczenie powinności. 3. Język wartości moralnych. 4. Podsumowanie.

Opisując rzeczywistość moralną, niejednokrotnie posługujemy się językiem wartości, który pomaga uchwycić intuicje moralne. Celem niniejszego artykułu będzie analiza języka wartości, którym posługiwał się Roman Ingarden. Zostanie ona przeprowadzona w odniesieniu do doświadczenia powinności i zagadnienia normatywności. Zbadam, jak krakowski fenomenolog opisuje wartości moralne i jakimi terminami posługuje się do tego opisu. Poszukam także odpowiedzi na pytania,

Andrzej Waleszczyński

a.waleszczynski@uksw.edu.pl
Uniwersytet Kardynała Stefana Wyszyńskiego w Warszawie, Instytut Filozofii

Wóycickiego 1/3, 01-938, Warszawa 
jaką rolę w mówieniu o wartościach odgrywają idee wartości i w jakim stopniu mogą one wskazać źródło powinności. Uzyskane odpowiedzi na postawione kwestie będą stanowiły punkt odniesienia dla pytania, jaka jest rola języka wartości w opisywaniu i komunikowaniu rzeczywistości moralnej.

Zanim jednak przejdę do języka, jakim Ingarden opisuje wartości, dokonam krótkiej rekonstrukcji jego poglądów w obszarze, który dotyczy podejmowanego przeze mnie problemu. W pierwszej kolejności skoncentruję się na typach wartości, następnie swoją uwagę przeniosę na sposób ich istnienia i konieczne warunki, które umożliwiają zaistnienie wartości moralnych. Na końcu zatrzymam się na czymś, co jest określane jako powinność zaistnienia wartości, czy też wartościowość wartości. Ukazanie złożoności i specyfiki stanowiska Ingardena pozwoli zobrazować, z jednej strony, doniosłość jego teorii, a z drugiej - odsłoni specyfikę języka, którym opisuje wartości i ich rozumienie. Niezbędne będzie również ukazanie roli, jaką odgrywa doświadczenie powinności. Ukazanie złożoności tego zagadnienia pozwoli w pełni zobrazować założenia teorii wartości moralnych. Dopiero po odtworzeniu jego stanowiska we wskazanym zakresie będę mógł przejść do krytycznej analizy stosowanego przez niego języka wartości.

\section{SPECYFIKA WARTOŚCI MORALNYCH}

Ingarden, odwołując się do literatury fenomenologicznej, wyróżnił trzy podstawowe dziedziny wartości. Do pierwszej przynależą wartości witalne, które blisko połączone są z wartościami użytecznościowymi (utylitarnymi) i przyjemnościowymi. Do drugiej zaliczył wartości kulturowe, wśród których wyróżnia wartości poznawcze, estetyczne i socjalne (obyczajowe). Natomiast trzecia dziedzina zawiera wartości moralne w węższym, bardziej precyzyjnym tego słowa znaczeniu ${ }^{1}$. Mnie interesować będzie ostatnia grupa z wymienionych wartości. Posługując się terminem 'wartość', należy zachować czujność, żeby nie mieszać obszarów, do których może się on odnosić. Istotne jest oddzielenie analiz

1 R. Ingarden, Czego nie wiemy o wartościach, w: Tenże, Przeżycie - dzieło wartość, Kraków 1966, 85. 
dotyczących wartości moralnych od innych badań, odnoszących się do wartości w ogóle, czy innych szczegółowych typów wartości, mimo że posługujemy się tym samym terminem. Chcę podkreślić, że nie interesuje mnie w tym momencie analiza sporu dotyczącego sposobu istnienia wartości, czy to moralnych, czy też innego typu. Zagadnienie sposobu istnienia wartości będzie poruszone, ale wyłącznie na marginesie prowadzonych wywodów. Punktem odniesienia w tym zakresie będzie stanowisko przyjęte przez krakowskiego filozofa, wskazujące na realność wartości.

Wartość jest zawsze wartością czegoś. Samodzielnie nie istnieje i musi być ugruntowana w przedmiocie realnym lub intencjonalnym. W związku z tym dla Ingardena wartości moralne mogą przysługiwać wyłącznie realnym osobom lub ich realnemu postępowaniu, gdyż bytowo są pochodną od własności swego nosiciela lub od układu własności kilku przedmiotów ${ }^{2}$. Wynika z tego, że np. moralna wartość sprawiedliwości może przysługiwać wyłącznie sprawiedliwej osobie lub jej czynom, które w momencie ich dokonywania są rozpoznawane jako sprawiedliwe. Wartość moralna odnosi się do tego, co jest realne, czego mogę doświadczyć. Wartości nie są ideami w sensie Platońskim, których nie ma $\mathrm{w}$ realnym świecie, doświadczalnym również empirycznie. Możemy wskazać pewne ideały, wzory do naśladowania lub postępowania, ale to są wyłącznie ideały, a nie realne wartości. Pragnę również zwrócić uwagę na pewną dwoistość ujmowania wartości. Wartości moralne mogą istnieć nie tylko w momencie zaistnienia czynu ludzkiego, ale także przynależeć osobom. Ukazuje to wyraźnie, że wartości nie istnieją samodzielnie, same w sobie, ale także to, że dla Ingardena dokonuje się moralne wartościowanie nie tylko czynów, ale także osób. Na gruncie etyki jest to podejście, które różni się od stanowiska, oddzielającego w wyraźny sposób wartościowanie czynów od oceny podmiotów moralnych. Dlatego w poglądach Ingardena można mówić właśnie o wartościach moralnych osób i czynów. W szerszej perspektywie będzie to powodowało pewne konsekwencje i trudności natury etycznej.

2 Tamże, 92, 102-103. 
Ingarden jednoznacznie odcina się i krytykuje poglądy, które traktują wartości jak przedmioty idealne czy idee, znajdujące się poza czasem lub w świecie idei. Tym samym jednoznacznie odrzuca propozycje przedstawione w tym zakresie nie tylko przez Platona, ale także m.in. przez Maxa Schelera i Nicolai Hartmanna. Według niego, wartość moralna pewnego czynu powstaje w chwili dokonania indywidualnego czynu, a gdy nie ma danego przedmiotu (czynu), wartość przestaje istnieć ${ }^{3}$. Dlatego też człowiek zdobywa pewną zasługę w momencie dokonania czynu. Wartość pojawia się na „barkach” jego czynu. Zwraca szczególną uwagę, że realne istnienie wartości uprawomocnia jej ocenę. Twierdzi, że warunkiem wydania jakiejkolwiek oceny jest modus existentiae wartości. Oceniając coś jako wartościowe, odnosimy się do pewnej zastanej rzeczywistości. Jeżeli coś takiego nie istniałoby, to powinniśmy zaprzestać dokonywania ocen, gdyż jest to, według Ingardena, nieuprawniony sposób postępowania ${ }^{4}$.

Krakowski filozof podejmuje szczególnie interesujące zagadnienie i pyta: „Czy wartość czynu przemija tak samo jak czyn, który się dokonuje i po dokonaniu więcej nie istnieje? Czy też trwa ona, pozostaje po przeminięciu samego czynu?"5 Pyta również przewrotnie, czy można być nagradzanym lub karanym za coś, czego już nie ma. Rozwija swój pogląd i wskazuje, że dokonany czyn pozostawia na człowieku pewien ślad zasługi lub zbrodni. W wymiarze społecznym doceniamy działania osób, które wykazały się bohaterstwem, dobroczynnością, uczciwością, mimo że ich czyny przeminęły. Zdaniem Ingardena jest to możliwe ze względu na pewną aktualną wartość tego człowieka. Takie postępowanie jest uzasadnione, gdy wartości rozumiemy w sposób Ingardenowski. Według niego pozostają one w jakiś sposób na sprawcy czynu. W innym przypadku nagradzanie lub karanie, na co wskazuje, rozwijając swój pogląd, nie ma sensu. Wartości nie tylko są w stanie przetrwać upływ czasu, ale także wraz z jego upływem nie ulegają żadnym zmianom co do natury wartości i jej wysokości. Tylko wtedy człowiek może ponosić odpowiedzialność za czyny chwalebne lub haniebne.

Tamże, 93, 106.

R. Ingarden, Wykłady z etyki, Warszawa 1989, 165.

R. Ingarden, Czego nie wiemy o wartościach, dz. cyt., 93, 107. 
Dla zaistnienia wartości moralnych muszą być spełnione jeszcze pewne warunki. Autor Wykladów z etyki wskazuje jednak, że nawet rozumowe zbadanie i wyjaśnienie zespołu warunków niezbędnych dla zaistnienia wartości, nie pozwala dotrzeć do natury wartości moralnych. Innymi słowy, spełnienie wszystkich warunków nie decyduje o zaistnieniu wartości, a wyłącznie stwarza możliwości ich zaistnienia. Dwoma warunkami, na które wskazuje Ingarden, koniecznymi, chociaż niewystarczającymi, są: wolność i samoświadomość . Bez dobrowolności czynu nie można mówić o jego wartości. Wartość moralna czynu jest związana z momentem wolitywnym, z momentem chcenia. Podobnie świadomość dokonywania czynu wpływa na to, czy czyn podlega ocenie moralnej. Zdrowie psychiczne człowieka wiąże się z możliwością wzięcia odpowiedzialności za dokonane czyny. Bez tych dwóch warunków nie można mówić o wartościach moralnych. Dlatego też, jak twierdzi Ingarden, sam układ rzeczy, czyli zaistniała sytuacja, ale bez świadomości i dobrowolności jej zaistnienia, nie wpływają na powstanie wartości. Czyny dokonywane pod przymusem i nieświadomie wymykają się ocenie etycznej.

Wartości nie tylko istnieją realnie, ale także posiadają swoją „wage", pewną doniosłość, wysokość. Owa waga, doniosłość wartości, stanowi o jej wartościowości. Innymi słowy, natura wartości określa jej rangę w stosunku do innych wartości, jak również nakłania do jej realizacji. Cechą charakterystyczną wartości moralnych jest właśnie to, że istnieje w nich coś, co pociąga podmiot moralny ku sobie, skłania do dokonania konkretnego wyboru. W sytuacji konfliktowej, gdy człowiek musi wybrać pomiędzy dwiema różnymi wartościami, to coś wskazuje, którą z nich „należy” wybrać. Jest to związane z tym, że wartości zawierają w sobie postulat zaistnienia ich realizacji, który w szczególny sposób modyfikuje sposób ich istnienia. W języku niemieckim ta „powinościowość" jest określana jako Seinsollen (powinność zaistnienia) i w przypadku wartości moralnych ma bezwzględny charakter. Oznacza to, że w sytuacji możliwości zrealizowania jakiejś wartości moralnej,

$6 \quad$ Tamże, 87. 
uniknięcie jej zaistnienia powoduje powstanie negatywnej wartości moralnej, czyli zła moralnego ${ }^{7}$.

O powinności zaistnienia można mówić, zdaniem Ingardena, sensownie w dwóch różnych przypadkach. Po pierwsze, gdy wartość jeszcze nie została zrealizowana. Po drugie, gdy dana wartość została zrealizowana. Skoncentruję się na pierwszej sytuacji, istotniejszej dla naszych analiz, w której mamy do czynienia z ,powinnościowością” istnienia. Ingarden sugeruje, że możemy wyczytać ją z zawartości idei danej wartości, np. sprawiedliwości. W momencie pojawienia się możliwości realizacji jakiejś wartości moralnej, mamy sytuację, w której, z jednej strony, nie musi zaistnieć dana wartość, jednak z drugiej - materia wartości domaga się od tych, którzy posiadają takie możliwości, jej konkretyzacji. Dlatego też owemu ,powinno być” (Seinsollen) towarzyszy założenie, iż ,jeszcze nie jest”. Istotą tego ,powinno być” nie jest przyczynowo-skutkowa relacja, w której przewiduję, co nastąpi, i oczekuję tego. Jest to coś więcej. Same warunki niezbędne do zaistnienia wartości są niewystarczające dla jej realizacji. Innymi słowy, w pewnych okolicznościach i określonych warunkach może zostać zrealizowana wartość moralna. Jej „wartościowość” domaga się jej realizacji, a dokonanie tego spowoduje, że będzie wszystko „w porządku”, bo w danym momencie jeszcze nie jest. Natomiast człowiek, który dokonuje realizacji danej wartości, podlega swoistemu obowiązkowi, owej powinności. Gdy ją realizuje, też staje się „w porządku”, gdyż tak naprawdę nie podlega żadnemu przymusowi ich realizacji. W tym przykładzie ujawnia się m.in. specyfika wartości moralnych i jest związana z dobrowolnością ich realizacji ${ }^{8}$. Istotne jest to, że „powinnościowość”, wyznaczona przez zawartość idei danej wartości, nie zachodzi już, gdy wartość zostanie efektywnie ,zrealizowana”, skoro więc zostanie „wypełnione domaganie się jej realizacji"'. Inaczej mówiąc, efektywne istnienie wartości jest związane z wypełnieniem dostrzeżonej powinności. To, co jest

\footnotetext{
Tamże, 98.

Tamże, 109-110.

9 Tamże, 110.
} 
charakterystyczne dla zaistnienia wartości, to nie tyle samo Sollen, ale właśnie jego wypełnienie, jego realizacja ${ }^{10}$.

Ingarden analizuje także transcendentalną powinność, związaną z pewnym stanem rzeczy, który powinien być realizowany. $\mathrm{W}$ tej sytuacji powinność odnosi się do pewnego układu rzeczy, a nie do konkretnego przedmiotu. Ukazuje to, co bywa realizowane, a dotyczy to np. sprawiedliwości, czyli szczególnego układu kilku przedmiotów wartości. Dla tego stanu rzeczy charakterystyczne jest to, że nie jest on nadany przez jakąś ludzką wolę ${ }^{11}$. Chodzi o to, że powinność nie jest związana z ideałem realnej i konkretnej wartości, która może zostać urzeczywistniona, ale przekracza jednostkową wartość i odnosi się do pewnego stanu rzeczy, czynów oraz związanymi z nimi wartości.

Jaka jest zatem relacja wartości moralnych do norm moralnych? W poglądach Ingardena uwidacznia się to w zależności między „etyką teoretyczną" a „etyką normatywną". Etyka teoretyczna zajmuje się wyjaśnianiem, czym są wartości, czego dotyczą, w jaki sposób istnieją, jakie są ich rodzaje. Natomiast etyka normatywna opisuje, czym są normy i wskazuje na treść nakazów. Istotne jest wszakże to, że etyka normatywna zakłada teoretyczną ${ }^{12}$. Analogicznie normy moralne zakładają istnienie wartości i swoją słuszność dla obowiązywania czerpią właśnie z istniejących realnie wartości. Krakowski fenomenolog analizując normę etyczną dokonuje jednak istotnego rozróżnienia na normę i rozkaz. Norma posiada zawsze ogólny moment normatywny i pewien wyróżnik, że ktoś „,coś” powinien. Natomiast rozkaz charakteryzuje się jednostkowym momentem imperatywnym, gdzie jego jednostkowość i jednorazowość dokonuje się w określonym momencie czasowym ${ }^{13}$. Tym samym nie zgadza się on np. z Husserlem, który mówi o sądach normatywnych. Dla Ingardena norma poprzez swój moment normatywny domaga się urzeczywistnienia pewnego stanu rzeczy. Jednak oprócz tego, posiada swoistą, jak określa, pretensję do „słuszności”, domagania się jej urzeczywistnienia. W ujęciu Ingardena bardzo istotne

\footnotetext{
10 Tamże, 111.

11 R. Ingarden, Wykłady z etyki, dz. cyt., 145-146.

12 Tamże, 16.

13 Tamże, 23.
} 
jest to, że zaprzeczenie normie jest przede wszystkim odrzuceniem pretensji do jej słuszności, a czymś wtórnym jest odrzucenie momentu normatywnego. Innymi słowy, podążając za jego tokiem rozumienia relacji między wartościami i normami, odrzucając normę, zaprzecza się przede wszystkim jej słuszności ${ }^{14}$. W przypadku nierozpoznania wartości czyn jest możliwy, ale następuje w wyniku ,ślepego” poddania się normie, obowiązkowi ${ }^{15}$. Inaczej przedstawiając to, nie następuje moment uznania „słuszności” normy lub jego odrzucenia. Wnioskuję, że w takiej sytuacji zostaje pominięta opisywana przez Ingardena postawa chceniowa ${ }^{16}$. Pozostaje tylko odruchowe działanie wywołane np. lękiem przed sankcją lub obawą przed odrzuceniem. Wydaje się, że w takiej sytuacji nie jest spełniony warunek świadomej realizacji czynu i realizacji wartości, bo mimo tego, że człowiek jest przy „zdrowych” zmysłach, to nie ma świadomości otaczającej go rzeczywistości.

\section{DOŚWIADCZENIE POWINNOŚCI}

Przechodząc do zagadnienia powinności, chcę zwrócić uwagę na istotne rozróżnienie, na które wskazuje Ryszard Moń, a które w rozważaniach natury etycznej jest niezbędne. Wyróżnia on powinność etyczną i moralną ${ }^{17}$. Pierwsza $z$ nich jest pojęciem etycznym, które powstaje wskutek odpowiedniej refleksji, i jest jednym z pojęć teorii moralności. Druga jest związana z moralnym postępowaniem człowieka. Odnosi się do mniej lub bardziej uzasadnionego działania, ale niebędącego wynikiem studiów nad tematem ludzkiego postępowania. Będę twierdził, że mówiąc o powinności moralnej, wskazujemy na jej (osobiste) doświadczenie. Doświadczenie powinności moralnej wydaje się być przeżywane jako bezpośrednio dane, wewnętrzne przynaglenie, które jest związane z konkretną jednostkową sytuacją. Będę także utrzymywał, że mimo bezpośredniości i wewnętrzności tego doświadczenia,

\footnotetext{
14 Tamże, 25.

15 Tamże, 113.

16 Tamże, 106-108.

17 R. Moń, Warto czy należy? Studium na temat istoty i źródel normatywności, Warszawa 2011, 378.
} 
charakteryzuje się ono także swoistą autonomią czy też niezależnością. Tak rozumiana powinność moralna staje się źródłem uznania słuszności czynu i punktem odniesienia dla konstruowania jego uzasadnienia. Mając na uwadze poczynione rozróżnienie, można przejść do zagadnienia powinności w ujęciu Ingardena.

Jak wspomniałem, w przypadku wartości moralnych istotna jest „powinność” zaistnienia wartości, owo Seinsollen. Ingarden zwraca uwagę, że o „powinności” zaistnienia pewnej wartości można sensownie mówić w dwóch różnych sytuacjach. W pierwszej, gdy jeszcze wartość nie zaistniała, i w drugiej, gdy się to już dokonało. Ze względu na problem, który chcę wskazać, interesować mnie będzie pierwszy przypadek, w którym ,powinnościowość” istnienia można wyczytać z zawartości ogólnej idei danej wartości. W przypadku konkretyzacji wartości mówimy o jej realizacji i jej zaistnieniu. To „powinno być” wartości zakłada, że ,jeszcze nie jest” i oznacza mniej więcej tyle, iż w przypadku jej realizacji będzie wszystko „w porządku”. Innymi słowy to, co doświadczamy jako powinność moralną, ma swoje źródło w ogólnej idei danej wartości. Należy pamiętać, że ogólna idea danej wartości i sama wartość, którą możemy zrealizować, nie są ze sobą tożsame.

$\mathrm{W}$ tym momencie interesuje mnie udzielenie odpowiedzi na pytanie, jaka jest relacja między ogólną ideą danej wartości a konkretną wartością. Problem dotyczy sprawstwa i porządku poznawczego. Jeżeli najpierw musiała zaistnieć wartość, a wraz z nią konkretny czyn czy też szereg czynów danego typu, to ogólna idea wartości jest czymś wtórnym w stosunku do wartości. Przyjmując taki porządek rzeczy, najpierw musimy doświadczyć lub rozpoznać dane czyny jako wartościowe, żeby móc wyabstrahować z nich ogólną ideę danej wartości. Jednak przy takim założeniu to, co powinne, nie może się jawić jako takie, dopóki nie doświadczymy lub nie rozpoznamy danego czynu jako wartościowego. Problem dotyczy samego początku, czyli pierwszego czynu z klasy danych czynów. W konsekwencji wynikałoby z tego, że jeżeli np. nie doświadczymy miłosierdzia, nie zaobserwujemy aktów miłosierdzia lub nie zostaniemy poinformowani o aktach miłosierdzia, to nie zaistnieje powinność czynienia aktów miłosierdzia. I chcę tu podkreślić, że nie chodzi mi o terminologię, ale o doświadczenie powinności odniesione do realizacji danej wartości. Ujmując to od innej 
strony, przyjmując porządek zaproponowany przez Ingardena, czyli przejścia od wartości do ogólnej idei wartości, napotykamy problem powstania powinności zaistnienia nowej wartości, czyli czynu, który byłby pierwszy z klasy danych czynów. Problem ten dotyczy zarówno wymiaru indywidualnego, jak również społecznego. Zagadnienie wydaje się istotne, bo wszystko wskazuje na to, że Ingarden budując całą swoją teorię wartości, wyszedł właśnie od doświadczenia powinności. Doświadczenia tego, że podmiot czuje/dostrzega wewnętrzne przynaglenie do realizacji czegoś, co Ingarden nazywa wartością.

Można próbować ominąć ów problem, przyjmując, że nowa wartość może zaistnieć mimowolnie przy okazji realizacji innej wartości lub w wyniku przypadkowego czynu. Jednak takie rozwiązanie, jak już wspominałem, w kontekście poglądów Ingardena jest nie do przyjęcia, gdyż wartość moralna może zaistnieć wyłącznie, gdy czyn jest wolny i świadomy. Czyn dokonany odruchowo, mechanicznie nie powoduje zaistnienia wartości moralnej. Jeżeli ktoś nie jest świadomy realizacji wartości, to równocześnie nie może być jej twórcą.

Odwracając porządek i przyjmując, że przechodzimy od ogólnej idei wartości do wartości moralnej, napotykamy trudności innej natury. Nie będę zatrzymywał się nad rozwiązaniem zaproponowanym przez M. Schelera, który uznawał istnienie wartości na sposób idealny, gdyż krytyki tego stanowiska dokonał już sam R. Ingarden. W sytuacji przejścia od ogólnej idei wartości do wartości moralnej, ogólna idea wartości byłaby konstrukcją myślową powstałą w oderwaniu od tego, czym jest wartość, bo jeszcze ta wartość nie zaistniała, nie została doświadczona, gdyż nie zaistniał czyn, który byłby pierwszym czynem z danej klasy czynów. W związku z tym, trudno jest mówić o ogólnej idei wartości bez odniesienia do realnej wartości, chyba że przyjmiemy, iż owa ogólna idea wartości jest swoistym ideałem, który możemy realizować, ale z którego nie wynika powinność, czyli w którym brak momentu zobowiązującego. W związku z tym, z jednej strony, jeżeli w ogólnej idei wartości brak jest owego ,powinien”, to trudno jest jej przypisać znaczenie, które nadawał jej Ingarden. Z drugiej strony, czy dana idea, wydedukowana lub założona a priori, jest rzeczywiście ideą wartości, możemy stwierdzić, realizując ją praktycznie. Jednak dopiero po realizacji idei wartości możemy stwierdzić, czy mieliśmy 
do czynienia z ideą wartości moralnej, czy jakąś inną ideą. Cały czas podnoszę problem zaistnienia pierwszego czynu z klasy danych czynów. Postaram się zobrazować to pewnym przykładem. Kobiety żyjące w wioskach w Kirgistanie czy Iranie nie wybierają sobie mężów. Często nawet nie wiedzą, że istnieją kultury, w których samemu można wybrać sobie współmałżonka. Moje pytania brzmią: jak miałaby powstać powinność samodzielnego wyboru męża, przed zaistnieniem pierwszego doświadczenia (rozumianego jako przeżycie lub rozpoznanie) wartości wynikającej z samodzielnego wyboru męża? Co powodowałoby, że daną ideę można byłoby uznać za ideę pewnej wartości moralnej, a nie pseudowartość, skoro musi być ona zrealizowana, aby istniała możliwość dostrzeżenia, iż jest ona wartością?

Na ciekawy wątek zwraca uwagę Karolina Rozmarynowska, analizując inne stanowiska dotyczące wartości. Dochodzi do wniosku, że jeżeli wartość byłaby rozumiana jako ideał postępowania, realizowany przez innego, który jest dla nas wzorem do naśladowania, to może stać się on dla człowieka celem jego działania. W związku z tym wartość można poddać interpretacji teleologicznej, w której urzeczywistnienie danej wartości może stać się czymś, do czego dąży człowiek ${ }^{18}$. Innymi słowy, jeżeli ktoś np. uznaje Jezusa za wzór do naśladowania, to ideałem postępowania - wartością - byłoby postępowanie tak jak on. Jednak takie podejście również nie rozwiązuje postawionego przeze mnie problemu, a jedynie dokonuje przesunięcia pewnego akcentu i nadania pojęciu wartości innego znaczenia. W tym przypadku wartość jest ideałem, wzorem, a nie czymś realnie doświadczanym, a moc zobowiązująca pochodzi nie z wzoru, ale od autorytetu. To on przez urzeczywistnianie lub wskazanie wzoru postępowania nadaje jego realizacji charakter powinnościowy.

\section{JĘZYK WARTOŚCI MORALNYCH}

Posiadając ogląd dotyczący zagadnienia powinności, można przejść do problematyki odnoszącej się do języka. W celu opisania

18 K. Rozmarynowska, Znaczenie innego w doświadczeniu wartości, Studia Philosophiae Christiane 48(2012)4, 58. 
rzeczywistości moralnej Ingarden posługuje się terminem 'wartość'. Jednak sam wskazuje, że mówiąc o wartościach można odnosić się do trzech różnych dziedzin wartości: utylitarnych (i przyjemnościowych), kulturowych (poznawczych, estetycznych, obyczajowych) i moralnych. Już sam fakt istnienia trzech dziedzin, w których stosujemy jeden termin, wprowadza trudność komunikacyjną. Za każdym razem, gdy posługujemy się terminem 'wartość', powinniśmy doprecyzowywać, o jakich wartościach mówimy, czy są to wartości utylitarne, kulturowe czy moralne. Nastręcza to dodatkowe trudności z dwóch powodów. Po pierwsze, wymaga pogłębionej wiedzy i świadomości podmiotu uczestniczącego w procesie komunikacji o tym, czym są i jak istnieją wartości, po drugie, wymusza precyzyjne wyznaczenie obszarów i granic istnienia poszczególnych dziedzin wartości. Zakłada to posiadanie wysokiej kompetencji rozpoznawania wartości moralnych, gdyż wyznaczenie granicy pomiędzy wartościami przyjemnościowymi, obyczajowymi i moralnymi wymaga sięgnięcia do zagadnień ogólnofilozoficznych.

Jeszcze innym problemem jest współistnienie wielu wartości, np. moralnych i estetycznych. Zdarza się to, na przykład, w sytuacji, gdy mamy do czynienia z uwiecznieniem i rozpowszechnianiem jakiejś tragedii i zbrodni, ale kunszt artystyczny, za pomocą którego się to dokonuje, jest wręcz niespotykany. Dla przeciętnego uczestnika komunikacji społecznej, niezaznajomionego z problematyką wartości, pojawia się konflikt nie do rozstrzygnięcia, który może wskazywać na istnienie różnych i alternatywnych w stosunku do siebie światów wartości.

Kolejnym zagadnieniem jest sposób komunikowania wartości moralnych. Osoba, która doświadczyła pewnych wartości moralnych, mogła stworzyć ich idee. Jednak w momencie, gdy pragnie je zakomunikować, pojawia się pytanie, co przekazuje w języku. Treść, którą niesie język, nie zawiera momentu powinności, gdyż co najwyżej dokonuje on opisu idei lub sytuacji, które miałyby ją obrazować. Można by zastanowić się nad rolą wyobraźni w rekonstrukcji zasłyszanej idei, ale nie jest to przedmiotem niniejszego artykułu. Problem związany jest z pytaniem, co jest źródłem powinności w idei wartości moralnych? Jeżeli przyjmujemy, że idea wartości moralnej nie istnieje na sposób platoński, a jest pewnym wzorem dla postępowania, jak chce Ingarden, to skąd bierze się moment powinności jej realizacji. Sama idea 
rozumiana jako wzór postępowania i przekazywana w formie opisu, nie może go posiadać. Zapoznając się z nową ideą, nie wiemy, czy mamy do czynienia z wartością czy pseudowartością, gdyż za pomocą języka przekazywany jest jedynie jej opis. Z inną sytuacją mamy do czynienia, gdy podmiot samodzielnie konstruuje ideę jakiejś wartości. W takich okolicznościach może odnieść się do osobistych doświadczeń realnych wartości. Tak tworzona idea jakiejś wartości ma ugruntowanie w doświadczeniu realnej i konkretnej wartości. Można przyjąć, że poznając nową ideę wartości, przekazywaną przez drugiego, podmiot słuchający, dokonuje jej rekonstrukcji w oparciu o własne doświadczenia realnych wartości. Zasłyszany opis odnosi do własnych przeżyć i powinności doświadczonych w momencie spotkania konkretnych wartości. Rola języka wartości sprowadza się do funkcji drogowskazu, który pokazuje, gdzie szukać i w którą stronę podążać w poszukiwaniu analogicznych doświadczeń. Jednak to od osoby zależy, czy dokona takiej analogicznej rekonstrukcji idei.

Specyfika języka wartości ukazuje jeszcze jedną szczególną trudność, a mianowicie stopień komunikowalności idei wartości moralnych. To, że wartości moralnych nie można zakomunikować, a jedynie ich doświadczyć, w kontekście poglądów krakowskiego fenomenologa jest oczywiste. Przekazywalna jest jedynie idea danej wartości. Jednak idea ta w swoim opisie nie zawiera momentu powinności. Prawdopodobnie powstaje on w sytuacji rekonstrukcji idei w oparciu o własne doświadczenia wartości moralnych podmiotu. Uzgodnienie przekazywanej idei z ideą rekonstruowaną następuje jedynie na poziomie językowym. Natomiast na poziomie powinności i zobowiązań, rozbieżności uzależnione są od wielości i różnorodności doświadczeń wartości moralnych posiadanych przez podmioty, komunikujące między sobą ideę danej wartości. Innymi słowy, może zaistnieć sytuacja, w której w ramach dialogu społecznego nastąpi konsensus w sprawie akceptacji idei pewnych wartości, na poziomie ich opisu. Należy jednak pamiętać, że w ramach prowadzonego dialogu czy porozumienia następuje akceptacja wartości jedynie na płaszczyźnie językowej. Niekoniecznie jednak uzgodnienie rozumienia danej wartości jest jednoznaczne z uzgodnieniem zobowiązań wynikających z danej wartości. Dopiero wyrażenie zobowiązań w sposób normatywny może stanowić podstawę 
do tworzenia konsensusu na poziomie zobowiązań. Budowanie porozumienia społecznego w oparciu o język wartości może doprowadzić do sytuacji, w której zgoda wszystkich uczestników dialogu co do wartości, np. w ramach konsultacji społecznych, nie zakłada ich zgodnej normatywnej realizacji, np. w formie ustaw. Może być wręcz przeciwnie, dopuszcza taki sposób realizacji wartości, który nie jest do zaakceptowania przez jedną lub wiele stron dialogu społecznego jako wcielania w życie danej wartości.

Istnieje pokusa, żeby język wartości określić mianem języka porozumienia. Jest doceniany przede wszystkim przez tych, którzy promują ideę wolności jako najcenniejszą wartość. Mało kto będzie zaprzeczał temu, że tak nie jest. Jednak, jaka jest powinność realizacji tej wartości? Łatwiej jest dojść do porozumienia na pewnym metapoziomie, na którym wydają się funkcjonować wartości moralne, niż na poziomie norm ogólnych, nie mówiąc o poziomie norm szczegółowych. Niebezpieczeństwo natomiast kryje się w tym, że mówienie o wartościach zakłada normatywność, wynikającą z indywidualnych doświadczeń wartości i powinności. Gdy przechodzimy od języka wartości do języka norm, postrzeganie rzeczywistości staje się bardziej jednoznaczne, a tym samym łatwiej dochodzi do sytuacji problemowych. Dlatego też język norm wydaje się być postrzegany jako bardziej konfliktowy w stosunku do języka wartości, gdyż wymaga większej precyzji. Można by pokusić się o dokonanie opisu wartości językiem norm, jednak prawdopodobnie byłby to mniej atrakcyjny opis i prowadziłby raczej, posługując się typologią stosowaną przez Ingardena, do konieczności skonstruowania nowej etyki teoretycznej.

\section{PODSUMOWANIE}

Wydaje się, że Ingarden, konstruując swoją etykę, wyszedł od doświadczenia czegoś, co jest i być powinno, i opisał to w formie fenomenu wartości moralnej. W odróżnieniu od Schelera twierdził, że wartości moralne istnieją realnie, a nie idealnie. Przedstawiona przez niego argumentacja za realnym sposobem istnienia wartości, jest bardziej przekonująca, niż niemieckiego filozofa. Niemniej Ingarden wskazuje sytuacje, w których ujawnia się coś, co nazywa on wartością moralną oraz co 
domaga się realizacji i trwania. Przedstawiona w niniejszym artykule analiza wskazuje na to, że nie dokonuje on jednak rozróżnienia dwóch bliskich sobie doświadczeń: doświadczenia „wartości”, czyli momentu realizacji tego, co powinno być, oraz doświadczenia powinności, czyli, mówiąc językiem Ingardena, powinności zaistnienia wartości. Doświadczenie tego, co jest (powinne jako zrealizowane) i tego, co być powinno (powinne do zrealizowania), łączy ze sobą i wpisuje w wartość moralną jako realnie istniejąca. Dzięki takiemu zabiegowi może bardzo sprawnie dokonać opisu rzeczywistości moralnej. Doświadczenie konkretnej wartości moralnej pozwala, według Ingardena, skonstruować jej ideę. Następnie podmiot moralny znajdując się w nowych sytuacjach, może odczytać powinność z idei (wzoru) danej wartości. Jednak źródłem zobowiązania (powinności) nie jest idea (wzór) danej wartości, ale wartość (doświadczenie wartości), w oparciu o którą została skonstruowana idea (wzór) tej wartości. Jednak, jak wskazałem w niniejszym artykule, nie odpowiada to na pytanie, czy doświadczenie powinności może wyprzedzić doświadczenie wartości. Innymi słowy, czy można doświadczyć powinności do realizacji wartości moralnej, bez posiadania idei (wzoru) danej wartości, czyli bez jej uprzedniego doświadczenia? W świetle poglądów Ingardena wydaje się, że odpowiedź będzie przecząca. Prowadzi to jednak do sytuacji, w której nie ma możliwości zaistnienia nowych wartości, nowych w rozumieniu nowej klasy wartości. Oznaczałoby to, że przyjmuje się, iż zbiór wartości jest nie tylko skończony, ale również całkowicie rozpoznany. Rzeczywistość wydaje się temu zaprzeczać.

Dość umiejętnie udaje się Ingardenowi opisać doświadczenie powinności w języku wartości. Nie zapomina on także o towarzyszącym temu doświadczeniu momencie normatywnym. Jednak moją wątpliwość wzbudza sposób komunikowania momentu normatywnego, który zakładają wartości i który jest ujmowany właśnie za pomocą języka wartości. Istotny jest moment przejścia od idei (wzoru) wartości moralnych do norm ogólnych, jak również odwrotny, gdy normy zostają uogólnione i wyrażone w języku wartości ${ }^{19}$. Prowadzi to do wniosku,

19 W tym momencie sugeruję własną propozycję rozumienia wartości, której w tym miejscu nie będę rozwijał. Zasygnalizuję tylko, że wartość rozpatrywałbym 
że posługiwanie się językiem wartości, bardziej niż językiem norm, wydaje się fałszować komunikację w wymiarze moralnym.

\title{
BIBLIOGRAFIA
}

Ingarden R., Czego nie wiemy o wartościach, w: Tenże, Przeżycie dzieło - wartość, Wydawnictwo Literackie, Kraków 1966, 83-127. Ingarden R., Wyktady z etyki, PWN, Warszawa 1989.

Moń R., Warto czy należy?: studium na temat istoty i źródel normatywności, Wydawnictwo UKSW, Warszawa 2011.

Rozmarynowska K., Znaczenie innego w doświadczeniu wartości, Studia Philosophiae Christianae 48(2012)4, 55-66.

\section{ON THE EXPERIENCE OF OBLIGATION AND ROMAN INGARDEN'S LANGUAGE OF MORAL VALUES}

\begin{abstract}
When referring to moral reality, Roman Ingarden used the language of values. This article presents a description of moral values, and analyzes the terminology used to characterize them and explain their mode of existence. With regard to the theory of moral values, the experience of obligation and the problem of normativity are of crucial importance. An examination of both leads to questions about the way new classes of moral values emerge and the obligation to follow them is recognized. The discussion also reveals difficulties in the application of the language of values to the communication of moral issues.
\end{abstract}

Keywords: experience of obligation, norms, language of values, values, Roman Ingarden

jako swoisty wzór działania, istniejący na pewnym metapoziomie, który uogólnia i uniesprzecznia akceptowalne normy na drodze intuicji intelektualnej. 